\title{
Ammonite faunal dynamics across bio-events during the mid- and Late Cretaceous along the Russian Pacific coast
}

\author{
Elena A. Jagt-Yazykova \\ Acta Palaeontologica Polonica 57 (4), 2012: 737-748 doi: http://dx.doi.org/10.4202/app.2011.0076
}

The present paper focuses on the evolutionary dynamics of ammonites from sections along the Russian Pacific coast during the mid- and Late Cretaceous. Changes in ammonite diversity (i.e., disappearance [extinction or emigration], appearance [origination or immigration], and total number of species present) constitute the basis for the identification of the main bio-events. The regional diversity curve reflects all global mass extinctions, faunal turnovers, and radiations. In the case of the Pacific coastal regions, such bio-events (which are comparatively easily recognised and have been described in detail), rather than first or last appearance datums of index species, should be used for global correlation. This is because of the high degree of endemism and provinciality of Cretaceous macrofaunas from the Pacific region in general and of ammonites in particular.

Key words: Ammonoidea, evolution, bio-events, Cretaceous, Far East Russia, Pacific.

Elena A. Jagt-Yazykova [eyazykova@uni.opole.pl], Zakład Paleobiologii, Katedra Biosystematyki, Uniwersytet Opolski, ul. Oleska 22, PL-45-052 Opole, Poland.

This is an open-access article distributed under the terms of the Creative Commons Attribution License (for details please see creativecommons.org), which permits unrestricted use, distribution, and reproduction in any medium, provided the original author and source are credited. 